See discussions, stats, and author profiles for this publication at: https://www.researchgate.net/publication/328597250

\title{
The Use of Journal Writing in Teaching English Writing
}

Article · October 2018

1

2 authors, including:

Supiah Wagiyo

Institut Agama Islam Negeri, Indonesia, Bangka Belitung

5 PUBLICATIONS 1 CITATION

SEE PROFILE 


\title{
Penggunaan Journal Writing dalam Pembelajaran Menulis Bahasa Inggris \\ The Use of Journal Writing in Teaching English Writing
}

\author{
Supiah \\ Dosen Tadris Bahasa Inggris Stain SAS Babel \\ supiahwagiyo14@yahoo.co.id \\ Suzana \\ English Private Teacher \\ suzanachana@yahoo.com
}

\begin{abstract}
This article tries to give an alternative way to improve students' writing skills. Writing is still considered as the most difficult skill to be acquired since writing involves many aspects such as organization, content, mechanic, vocabulary, grammar etc. Writing is not only about product but also about process. It is called journal writing. Journal writing provides students an opportunity to improve writing. There are some kinds of journal writing which can be applied in teaching and learning writing such as personal journal, reading logs, learning logs, etc.
\end{abstract}

Keywords: journal, writing, learning, improve, skills

Abstrak

Artikel ini mencoba memberikan cara lain atau alternative yang mungkin dilakukan untuk meningkatkan kemampuan menulis siswa. Menulis masih dipandang sebagai salah satu dari empat kemampuan dalam pembelajaran bahsa Inggris yang sulit untuk dikuasai karena menulis itu sendiri adalah melibatkan beberapa aspek seperti susunan idea tau pemikiran, isi atau materi yang akan ditulis, kosakata, tata bahasa dan sebagainya. Teknik atau cara yang mungkin dapat digunakan untuk meningkatkan keterampilan menulis adalah journal writing. Ada beberapa jenis journal writing yang bias diaplikasikan oleh guru dan siswa dalam pembelajaran menulis seperti personal journal, reading logs, learning log dan sebagainya.

Kata kunci: jurnal, menulis, improve, learning, improve, keterampilan

\section{A. Introduction}

In Indonesia, English language has been introduced and learned as a foreign language in elementary school, junior high school, senior high school, and university level. English is a compulsory subject in Indonesian national curriculum for students in junior high 
school and senior high school. ${ }^{1}$ There are four language skills in English which students should acquire. They are listening, speaking, reading and writing.

Writing is a skill which requires students to express their ideas in written form. Writing involves complex process. ${ }^{2}$ As stated by Hogue, "writing is a process of creating, organizing, writing, and polishing". ${ }^{3}$ In line with Hogue, Rohmah has a notion "writing involves the mastery of all elements in the target language such as grammar, content, vocabulary, spelling and mechanics together". ${ }^{4}$ Moreover, the position of English as a foreign language for Indonesian students makes the subject of writing become more difficult for them. Consequently, students may have difficulties in doing this activity because it involves multifaceted process such as produce a particular feeling or impression, arrangement, script, and refinement.

Tompkins and Hoskisson cited in Rohmah stated that "the low quality of students' writing skill is caused by the strategy used by the teachers." 5 The strategy employed by the teacher may be ineffective; therefore the target of the learning process is not reached. Rohmah states that "the lack of exploring activity influenced the students' writing skill, especially skill in organizing their ideas". ${ }^{6}$ It means that the teachers should use different ways of teaching writing to improve the students writing skill.

According to the school-based curriculum of 2006, writing is one of skills taught at the junior high school by the teachers of English. Therefore, the teachers are demanded to be proficient in their writing ability. Many teachers feel that teaching writing is too difficult for

\footnotetext{
${ }^{1}$ Elan Dwi Winarno, Belajar Cepat Bahasa Inggris, (Yogyakarta: Pustaka Pelajar, 2008), p.1

${ }^{2}$ Galuh Nur Rohmah, How to Write Autonomously: Practical and Simple Guide to Improve the Students Writing Skill, (Malang: UIN Malang Press, 2009), p. 2.

${ }^{3}$ Ann Hogue, The Essentials of English: A Writer's Handbook, (New York: Pearson Education, 2003), p. 255.

${ }^{4}$ Galuh Nur Rohmah, How to Write......., p. 5

${ }^{5}$ Ibid., p. 4.

${ }^{6}$ Ibid., p. 5.
} 
students. However, it depends on the strategy, as Paul stated that "many common strategies of teaching reading and writing to both elementary and secondary school students are definitely too difficult for many Asian EFL learners, but there are alternatives that are not difficult. ${ }^{7}$ In this case, the teachers need some appropriate strategies of teaching writing that provide many opportunities for students to practice new structures in written form.

There are many strategies which can be used by teachers to teach writing. These strategies depend on the ability of the teacher to choose the appropriate one. One of the strategies which can be used to teach writing is journal writing. Hogue stated that "journal writings give the learner become fluent in written language". 8 Moreover, according to Langan, "journal writing will help students develop the habit of thinking on paper and will show the students how ideas can be discovered in the process of writing". ${ }^{9}$ In addition, the result of Ikayati's research described journal writing could improve students' writing skill. ${ }^{10}$ Additionally, Gebhard stated that "an alternative is to have students and teachers communicate with each other through journal writing". ${ }^{11}$ Thus, one of solutions to solve the problem above is by journal writing because journal writing can be used by teachers as his strategy in teaching writing.

Some of the purposes of a journal are record experiences, stimulate interest in a topic, explore thinking, personalize learning, develop interpretations, wonder, engage the imagination, ask question, active prior knowledge, assume the role of another person and

\footnotetext{
${ }^{7}$ David Paul, Teaching English to Children in Asia, (Hong Kong: Pearson Longman Asia ELT, 2003), p. 83.

${ }^{8}$ Ann Hogue, First Steps in Academic Writing: Second Edition, (New York: Pearson Longman, 2000), p. 173.

9 John Langan, College Writing Skill with Reading, (New York: McGraw-Hill Higher Education, 2001), p. 14.

${ }^{10}$ Ulfah Fitri Ikayati, “Teaching Writing Recount through Daily Activity”, Thesis, Faculty of Teaching Learning and Education University of Ibn Khaldun English Department, Bogor, 2009.

${ }^{11}$ Jerry Greer Gebhard, Teaching as a Foreign or Second Language: a Self-development and Methodology Guide, (Michigan: The University of Michigan Press, 2000), p. 235.
} 
share experiences with trusted readers. ${ }^{12}$ While Recount text tells someone's past experience in a chronological order. ${ }^{13}$ Therefore, journal writing is a good way as training in teaching recount text.

There are some reviews that have correlation with journal writing in improving writing. They are (1) Dr. Mohammed Farouk Abd El Sami Ali entitled his research in “Using Journal Writing for Developing EFL Pre-service Teachers' Writing Skills and Teaching Performance"; (2) Linda Addison entitled her research "A Teacher's Reflection on the Implementation of Journal Writing in Mathematics"; (3) Ulfah Fitri Ikayati entitled her research "Teaching Writing Recount through Daily Activity" and (4) Asti Kurnianingsih entitled her research "Writing Diary as an Alternative Technique in Teaching Written Recount Text".

The first review was the findings of the research conducted by Dr. Mohammed Farouk Abd El Sami Ali. He highlighted his research in "Using Journal Writing for Developing EFL Pre-service Teachers' Writing Skills and Teaching Performance"14. The results indicated that the students of the experimental group outperformed those of the control group in both writing skills and teaching performance. The study presented some recommendations for maximizing the practical use of journal writing and suggests some topics for further research.

Second, Linda Addison entitled her research as "A Teacher's Reflection on the Implementation of Journal Writing in Mathematics". She said that journal writing is one

\footnotetext{
${ }^{12}$ Gail E, Tompkins, Teaching Writing: Balancing Process and Product Second Edition, (New York: Macmillan College Publishing Company, 1994) Page 81-82

${ }^{13}$ Joko Siswanto, Yuniarti Dwi Arini, and Wasi Dewanto, Let's Talk, ( Bandung: Pakar Raya, 2005), Page 201

${ }^{14}$ Mohammed Farouk Abd El Sami Ali, "Using Journal Writing for Developing EFL Pre-service Teachers' Writing Skills and Performance", http://www.fayoum.edu.eg/English/Education/CurriculaTeaching/pdf/Journal.pdf, accessed on March 13, 2013.
} 
writing forms that may offer teachers an additional "tool" for teaching students mathematical concepts and evaluating mathematical knowledge. The rewards of the project for the teacher included an increased awareness of student comprehension of concepts, feelings and attitudes towards mathematics. Opening another line of communication with the students offered the opportunity to stay in touch with even the most quiet and reserved student. The personal journal offered the teacher a place in which to reflect upon the successes and challenges of Math Journals versus teaching mathematics. ${ }^{15}$

Third, Ulfah Fitri Ikayati entitled her research as "Teaching Writing Recount through Daily Activity"16. The results indicated that the best way to teach writing recount through daily activity both diary studies and journal writing are becoming increasingly popular about teaching and learning, because they are really good to application writing recount. The activities brought attention to the ways we get ideas, the ways we reason, the ways we structure and arrange, and above all the ways of writing for us.

Fourth, a research was conducted by Asti Kurnianingsih entitled "Writing Diary as an Alternative Technique in Teaching Written Recount Text" ${ }^{17}$ The population of this study is the eighth grades of SMP N II Bae, Kudus in the academic year 2009/2010. The subjects were 76 students. There were four meetings during the experimental research. Before the experimental research was conducted, a pretest was given (an essay test in the form of writing a recount text in the short paragraph). Besides, questionnaire was also given to support the data. The result of this research revealed that there was an improvement of

\footnotetext{
15 Linda Addison, "A Teacher's Reflection on the Implementation of Journal Writing in Mathematics", Thesis, master of education, the Faculty of Education of the University of Lethbridge, Alberta, 1995.

${ }^{16}$ Ulfah Fitri Ikayati, "Teaching Writing Recount through Daily Activity", Thesis, Faculty of Teaching Learning and Education University of Ibn Khaldun English Department, Bogor, 2009.

${ }_{17}$ Asti Kurnianingsih, "Writing Diary as an Alternative Technique in Teaching Written Recount Text", Thesis, Universitas Negeri Semarang, Semarang, 2009.
} 
students' achievement in writing recount who wrote diary as a strategy for the writing.

Students who wrote diary as the source for the recount text writing had better achievement than those who did not use diary as the source of the recount text writing.

\section{B. The Concept of Writing}

\section{Definition of writing}

Writing seems to be differently defined the definition vary from different people, needs and purposes. In the following, the researcher presents some definitions about writing. Klein states that "writing is the ability to put pen and paper to express ideas through symbols."18 It means that when we write, we produce meaning with words.

Moreover, Zinser cited in Ruddell confirmed that we need operate some kind of mechanism-pencil, pen, typewriter, word processor- for getting our thought on paper in writing. It urges us repeated efforts to go after those thoughts and to organize them and present them clearly. ${ }^{19}$ In addition, Manchon states "writing is central to our personal experiences, professional careers and social identities, yet while we are often evaluated by our control of it; its multifaceted nature constantly evades adequate description." 20

Furthermore, Peter Elbow cited in Brown states that writing is figuring out meaning and put it into language. ${ }^{21}$ As a result, writing is an activity of expressing the ideas through the signs or symbols in written form.

${ }^{18}$ Klein, Writing Definition Descriptive Text, Online, http:// en.writing-definition-descriptive-text, accessed on May 18, 2013.

19 Martha Rapp Ruddell, Teaching Content Reading and Writing, (New Jersey: Willey Jossey-Bass Education, 2005), p. 281.

${ }^{20}$ Rosa M. Manchon, Learning-to-Write and Writing-to-Learn in an Additional Language, (Amsterdam: John Benjamins Publishing Company, 2011), p. 17.

${ }^{21}$ H. Douglas Brown, Teaching by Principles: An Interactive Approach to Language Pedagogy Second Edition, (New York: Addison Wesley Longman, 2001), p. 336. 


\section{The Process of writing}

The writing process is a way of looking at writing instruction in which the emphasis is shifted from students' finished products to what students think and do as they write. $^{22}$ Likewise, Boyle cited in Peregoy and Boyle argues "process writing allows students to concentrate on one task at a time and to experience the value of peer feedback in developing their ideas for effecting written expression."23

Ruddell has organized the following description of writing process into the categories of before writing, during writing, and after writing. ${ }^{24}$ The following the description of the categories: ${ }^{25}$

\section{a. Before Writing: Prewriting}

Prewriting is frequently the foundation for a variety of writing, reading, thinking, and learning event. It might best described as mulling ideas over, whether immediately before beginning to draft a written piece or while simply thinking about what one knows about a given topic. As Tompkins states that "prewriting is the getting ready to write stage; during the prewriting stage in which the activities involving choosing a topic, considering, form, and audience, and generating and organizing ideas for writing." 26 Ruddell mentioned that "prewriting occurs in journals, logs, lists, diaries, e-mails, chat rooms, and maps."27

${ }^{22}$ Gail E. Tompkins, Teaching Writing ............., p. 7.

${ }^{23}$ Suzanne F. Peregoy, and Owen F. Boyle, Reading, Writing, and Learning in ESL: Fifth Edition, (Boston: Pearson Education, 2008), p. 231.

${ }^{24}$ Martha Rapp Ruddell, Teaching Content.........., p. 282.

${ }^{25}$ Ibid, p. 282-284.

${ }^{26}$ Gail E. Tompkins, Teaching Writing .............., p. 8

${ }^{27}$ Martha Rapp Ruddell, Teaching Content.........., p. 283. 


\section{b. During Writing: Drafting}

Drafting extends prewriting as students create a new text from what they have read, seen, thought about, or examined. ${ }^{28}$ To be more specific, the drafting stage is the time to pour out ideas, with little concern about spelling, punctuation, and other mechanical errors. The activities in this stage are writing a rough draft, writing lead and emphasizing content, not mechanics, Tompkins states. ${ }^{29}$

\section{c. After Writing: Revising, Editing}

The word revision means 'seeing again'. This stage demands writers to see their compositions again with their classmates and the teacher helping them. ${ }^{30}$ Peregoy and Boyle concluded that "revising is reordering arguments or reviewing scenes in a narrative; reordering supporting information; reviewing or changing sentences."31

Editing is correcting spelling, grammar, punctuation, and mechanics. ${ }^{32}$ Additionally, Tompkins stated that editing is putting the piece of writing into its final form. $^{33}$

\section{The Elements of Writing}

Oshima and Hogue stated that there are five elements in writing a paragraph. They are topic sentence, supporting sentences, concluding sentence, unity, and coherence. The following the explanation of those: ${ }^{34}$

\footnotetext{
${ }^{28}$ Ibid.,p. 284

${ }^{29}$ Gail E. Tompkins, Teaching Writing ............, p. 15

${ }^{30}$ Ibid,.....p. 16

${ }^{31}$ Suzzanne F. Peregoy and Owen F. Boyle, Reading, Writing......., p. 233.

32 Ibid., p. 234

${ }^{33}$ Gail E. Tompkins, Teaching Writing ............, p. 17

34 Oshima and Ann Hogue, Writing Academic English. (New York: Longman, 1999), p. 16
} 


\section{i.Topic Sentence}

The topic sentence is a sentence which states the main idea of paragraph. It is called the topic the paragraph and limits the topic that can be discussed completely in the space of single paragraph (controlling idea).

\section{ii.Supporting Sentences}

The supporting sentences are sentences that develop the topic sentences by giving reasons, examples, facts, statistic, quotation, comparison, definition, and classifications.

\section{iii.Concluding Sentence}

The concluding sentence is a sentence which signals the end of the paragraph and leaves the reader with important points to remember.

\section{iv.Unity}

Unity means that there is only one main idea in the paragraph. The main idea is stated in the topic sentence and then each and every supporting sentence develops.

\section{v.Coherence}

Coherence means that the paragraph is easy to read and understand because the supporting sentences are in some kind of logical order, and the ideas are connected by the use of a appropriate transition signals. 
Journal writing can be applied in teaching and learning English writing for example teaching recount text. Recount text tells someone's past experience in a chronological order, Siswanto confirmed ${ }^{35}$

Recount tells the reader what happened. As Pradini clarified "recount text tells about facts or true stories organized in chronological series of events. ${ }^{36}$ Recount retells events for the purpose of informing or entertaining. ${ }^{37}$ The purpose of a recount is to list and describe past experiences by retelling events in the order in which they happened with the purpose of either informing or entertaining their audience. ${ }^{38}$

Example of recount text

$$
\text { My Grandpa’s Birthday }
$$

It was my grandpa's birthday last Sunday. On Friday, my sister and I went shopping. We found a nice batik shirt. We bought it and wrapped it in a blue paper. Blue is my grandpa's favorite color.

On Saturday morning, my brother and I helped our sister in the kitchen. We made a birthday cake. It was a big and beautiful cake. I wrote Happy Birthday on it. We put some chocolate and a big candle on top of it.

On Sunday evening, we had a party. My uncle and my aunt came to my house. They brought some coke and flowers for my grandpa. We sat together in our living room. My dad said a beautiful prayer. Then, we sang 'Happy Birthday" and my grandpa blew out the candle. He cut the cake and gave it to everybody in that room. He opened his present and he was very happy with the shirt. Finally, my grandma told us some stories about my grandpa. ${ }^{39}$

In short, it could be concluded that recount text is a text which informs the past event experiences in words sequentially. Recount also has intention to occupy and divert the reader.

35 Joko Siswanto, Yuniarti Dwi Arini, and Wasi Dewanto, Let's Talk, ( Bandung: Pakar Raya, 2005), p. 201.

${ }^{36}$ Amalia Pradini, Exploring How Recount Text Works, (Jakarta: PT. Multazam Mulia Utama, 2010), p. 8

${ }^{37}$ Linda Gerot and Peter Wignell, Making Sense of Functional Grammar, (Sydney: Gred Stabler, 1994), p. 194.

${ }^{38}$ Amalia Pradini, Exploring How .......,p. 8.

${ }^{39}$ Mukarto, at al, English on Sky SMP Book 1, (Jakarta: Erlangga, 2004), p. 131. 


\section{Generic Structure of Recount Text}

According to Garot and Wigmel, there are 3 part of generic structure of recount text.

They are: ${ }^{40}$

\section{a. Orientation}

Orientation provides the setting and introducing the participant, using first point of view.

\section{b. Events}

In this part, the writer tells and describes a series of event which happened.

\section{c. Re-orientation}

It states the writer's personal note. It is optional-closure of events.

\section{Language Features of Recount Text}

Pradini stated that there are seven language Features of recount text as follow: ${ }^{41}$

a. Using specific participant; the characters involve in the story is specific not general, e.g: RA Kartini, My friend, Jhon, Christian Bautista, etc.

b. Using chronological connectives or time conjunction; to connect flows in the stories systematically and easy to be understood. The common conjunctions in recount are: when, then, next, after that, etc.

c. Using linking verb; was, were

d. Using action verb to show action; in recounts, there are action verbs where the activities can be seen, e.g.: moved, left, walked, made, etc.

e. Using simple past tense as it tells events that happen in the past, e.g.: earthquake happened, I was on the car, my car lunched on one side, etc.

\footnotetext{
${ }^{40}$ Linda Gerot and Peter Wignell, Making Sense of............, p. 194

${ }^{41}$ Amalia Pradini, Exploring How .......,p. 8-9
} 
f. Using relational verbs to connect the subjects and their complements.

g. Using adjective to modify noun; e.g.: a beautiful donkey, a vicarious journey, a high hill, a scary man, etc.

\section{Types of Recount Text}

A writer or speaker uses a recount to tell us about a story or an event. Recounts are usually given in the order that the event occurred. As Pradini stated, it can be: ${ }^{42}$

\section{a. Factual Recount}

Factual recount is to record the particulars of an accident. Such as report of scientific experiment, police report, news report, historical account.

\section{b. Procedural Recount}

Procedural recount is to inform listeners or readers. It records events such as a science experiment or a cooking experience. It also presents the events chronologically (in the order in which they happened). Such as telling someone how you built something.

\section{c. Personal Recount}

Personal Recount is to retell an event that the writer was personally involved in. such as a family holiday or your opinion on a subject.

\section{d. Imaginative Recount}

Imaginative recount is to take on an imaginary role and give detail of events.

${ }^{42}$ Ibid.,p.9-10 


\section{e. Historical Recount}

Historical recount is to inform by retelling past events and achievements in a person's life. It was specific names of the people involved in the biography. It presents the events chronologically.

\section{b. The Concept of Journal Writing}

\section{Journal Writing}

Physically, journal could be a bound note book, a ring binder full of papers, a collection of electrical particles on computer disk or an audio tape. Journal writing provides students an opportunity to improve writing. According to Ann Hogue, Journal writing is one way to get and develop idea. ${ }^{43}$ Moreover, Patricia states that the journal writing strategy provides teachers with multiple opportunities to integrate the language arts across the curriculum. ${ }^{44}$ Additionally, journal writings give the learner become fluent in written language. ${ }^{45}$ Since, journals are forms of self-report which allow learners to record their thoughts, feelings, achievements, and problems, as well as their impressions of teachers, fellow students, and native speakers. ${ }^{46}$ Therefore, journals encourage introspection and reflection because the learners are essentially writing to and for themselves (with an eye, of course, on the teacher's response if one is to be given). ${ }^{47}$ As

\footnotetext{
${ }^{43}$ Ann Hogue, The Essentials ............. p. 256.

${ }^{44}$ Patricia A Antonacci and Catherine M. O Callaghan, A Handbook for Literacy Instructional \& Assessment Strategies K-8, (Boston: Pearson A \& B, 2006), p. 110.

45 Ann Hogue, First Steps .............., p. 173.

${ }^{46}$ Rebecca L. Oxford, Language Learning Strategies: What Every Teacher Should Know, (Boston: Heinle \& Heinle Publisher, 1990), p. 198.

47 Jeremy Harmer, How to Teach Writing, (Essex: Pearson education Limited, 2004) p. 125.
} 
well, Kristine Brown stated that "journal writing also demonstrates one way to encourage learners to reflect on their own learning in a structured way." ${ }^{48}$

In line with Brown, Caroline Coffin, Marry Jane Goodman, Ann Hewings, Theresa M. Lilis and Joan Swann stated the keeping of journals can also constitute another form of prewriting. Student journals can serve multiple functions and take various forms, from bound notebooks to electronic mail entries. Journals provide an opportunity for an informal, personal type of writing in which students can make observations, reflect on questions set by the lecturer, respond to course materials, and ask questions without the constraints of creating a formal text. In this case journals can be used as vehicles for student learning and include both their preliminary responses to set assignments or questions as well as students' own explorations. Students can draw on the ideas they develop in journal entries as they craft their more formal, assessed texts. Many students, including non-native English speakers, benefit from the frequent practice that writing regular journal entries can provide. ${ }^{49}$

Additionally, Tompkins states that some of the purpose of a journal is record experiences, stimulate interest in a topic, explore thinking, personalize learning, develop interpretations, wonder, engage the imagination, ask question, active prior knowledge, assume the role of another person and share experiences with trusted readers. ${ }^{50}$

48 Kristine Brown, Monitoring Learner Progress, (Melbourne: National Centre for English Language Teaching and Research Macquarie University, 1999), p. 35.

${ }^{49}$ Caroline Coffin, Marry Jane Goodman, Ann Hewings, Theresa M. Lilis and Joan Swann, Teaching Academic Writing: A Toolkit for Higher Education, (London: Routledge, 2003), p. 36.

${ }^{50}$ Gail E Tompkins, Teaching Writing: Balancing Process and Product Second Edition, (New York: Macmillan College Publishing Company, 1994), p. 81-82. 
Concluding the statements above, journal writing is a past event which tells about the writer's occurrence, the writer's feeling, and the writer's thought about something that have just happened and it is liberated written form.

\section{The Type of Journal Writing}

There are five kinds of the journal, as explained by Tompkins. They are: ${ }^{51}$

\section{a. Personal journal}

Student can keep personal journals in which they recount the events in their lives and write about topics of their own choosing.

\section{b. Dialogue journals}

Students and teachers carry on a private conversation with each other through writing. Students write informally to the teacher about something of interest or a concern, and the teacher responds.

\section{c. Reading logs}

Students write in reading logs about stories and other books they are reading during literature focus units and readers' workshop. Students can also list unfamiliar words, jot down quotable quotes, and take notes about characters, plot, or other elements of the story. And the primary purpose of this journal is for students to think about the book, connect literature to their lives, and develop their own interpretations.

\section{d. Learning logs}

Students use learning logs to record or react to what they are learning in social studies, science, or math. Students write in this journal to reflect on their learning, to discover gaps in their knowledge, and to explore relationships between what is learning and their past experiences.

\footnotetext{
${ }^{51}$ Ibid., p. 78.
} 


\section{e. Simulated journal}

Students assume the role of another person and write from that person's viewpoint. As students read biographies or study social studies units, they can assume the role of a historical figure. As they read stories, they can assume the role of a character in the story. In this way, students gain insight into the lives of other people and into historical events.

\section{The Benefits of Journal Writing}

The benefits of journal writing are the value of reflection, freedom of expression, developing writing skills, and student-teacher dialogue. The following the explanation of those: ${ }^{52}$

\section{a. The value of reflection}

Journals provide an opportunity for students to think both about how they are learning and also about what they are learning. This kind of introspection may well lead them to insights which will greatly enhance their progress.

\section{b. Freedom of expression}

Journals allow students to express feeling more freely than they might do in public, in class. They can decide what and how much they want to include and they can write at their own speed.

\section{c. Developing writing skills}

The more students write the better and more fluent they become as writers. They expand their range of written expression and write with greater ease and speed.

\footnotetext{
${ }^{52}$ Jeremy, Harmer, How to teach .........., p. 126-128.
} 
Journal writing contributes to a student general writing improvement in the same way as training enhances an athlete's performance: it makes them fit.

\section{d. Student-teacher dialogue}

One of merits of journal (and letter) writing is the dialogue it encourages between teacher and students. When a student writes in a journal, she or he knows that the teacher will read what is written with, perhaps, a different eye from the normal evaluative one. A different kind of conversation therefore takes place.

\section{The Steps for Improving Students' Writing Skill through Journal Writing}

Structure is probably the most important element of successful journal writing ventures. Ruddell explore the element into 4 steps. They are: $:^{53}$

a. Decide why you're doing journal writing and how it reflects instructional goals. Consider carefully your reasons and have them ready to explain to students.

b. Determine and state explicitly what the daily, weekly, and semester-long policies and procedures are for the journal writing. Consider and make decisions about all of the following:

1) What effect, if any, will journal writing have on students' grade?

2) When is the best time to write-beginning or end of class?

3) How often shall we write?

4) Shall we simply write, or shall we use a letter-to-the-teacher format, or do I want to develop daily prompts?

5) What is reasonable timeline and routine for reading and responding to students' journal?

\footnotetext{
${ }^{53}$ Martha, Rapp Ruddell, Teaching Content ............, p. 304.
} 
c. Develop and list expectations for student behavior. Consider and make decisions about all of the following:

1) Where will I locate journal? Will students bring them, or will I store them? (Many teachers keep journals in their room if they don't have to change rooms. This eliminates many hassles.)

2) How will students get journals kept in the classroom? What is the consequence if students forget to bring their journals from their lockers?

3) What is the signal to start writing? What is the signal to stop?

d. Develop and list expectations for teacher behavior.

1) What will I be doing while students are writing?

2) Will I write and share my writing with students?

3) What will be the focus of my response to students' writing?

4) How much of each student's writing will I read and respond to?

5) What is my commitment for returning journals after I've collected them?

\section{CONCLUSIONS}

In the process of learning, the students need a series of writing process using journal writing well. In process of learning the students needed so much attention from their teacher. They would write enthusiastically when the teacher gave them much motivation and responses about what they have written. The students needed appreciation in learning process. By using journal writing in learning writing process almost all of the students get what they want. It also requires the teacher to support students to write as well as to evaluate it. Therefore, journal writing can be very profitably exploited in language learning activities, especially in teaching writing. The teachers of English 
needs to vary the technique of teaching writing. Moreover, the teacher should be creative and innovative in using appropriate teaching strategy. One of the appropriate strategies is journal writing. The teacher has also motivates students to write. Not only by speaking but also by writing. Teachers may create good learning environment, increasing the frequency of students writing activities and giving enjoyable and interesting materials (topic of writing). In addition the students have to practice English a lot, either speaking or writing. Students should improve their writing skills and increase their knowledge of grammar, vocabulary and the other aspects of writing as the supporting elements in writing. The last, the students need to share knowledge to their friends who had lower knowledge.

\section{References}

Amalia Pradini, Exploring How Recount Text Works, (Jakarta: PT. Multazam Mulia Utama, 2010)

Ann Hogue, First Steps in Academic Writing: Second Edition, (New York: Pearson Longman, 2000

Ann Hogue, The Essentials of English: A Writer's Handbook, New York: Pearson Education, 2003

Asti Kurnianingsih, "Writing Diary as an Alternative Technique in Teaching Written Recount Text”, Thesis, Universitas Negeri Semarang, Semarang, 2009.

Caroline Coffin, Marry Jane Goodman, Ann Hewings, Theresa M. Lilis and Joan Swann, Teaching Academic Writing: A Toolkit for Higher Education, London: Routledge, 2003

David Paul, Teaching English to Children in Asia, (Hong Kong: Pearson Longman Asia ELT, 2003

Elan Dwi Winarno, Belajar Cepat Bahasa Inggris, (Yogyakarta: Pustaka Pelajar, 2008),

John Langan, College Writing Skill with Reading, (New York: McGraw-Hill Higher Education, 2001

Gail E, Tompkins, Teaching Writing: Balancing Process and Product Second Edition, (New

York: MacMillan College Publishing Company, 1994)

Galuh Nur Rohmah, How to Write Autonomously: Practical and Simple Guide to Improve the Students Writing Skill, (Malang: UIN Malang Press, 2009) 
H. Douglas Brown, Teaching by Principles: An Interactive Approach to Language Pedagogy Second Edition, (New York: Addison Wesley Longman, 2001)

Jeremy Harmer, How to Teach Writing, (Essex: Pearson education Limited, 2004)

Jerry Gebhard, Teaching as a Foreign or Second Language: a Self-development and Methodology Guide, (Michigan: The University of Michigan Press, 2000)

Joko Siswanto, Yuniarti Dwi Arini, and Wasi Dewanto, Let's Talk, ( Bandung: Pakar Raya, 2005)

Klein, Writing Definition Descriptive Text, Online, http:// en.writing-definition-descriptive-text, accessed on May 18, 2013.

Kristine Brown, Monitoring Learner Progress, (Melbourne: National Centre for English Language Teaching and Research Macquarie University, 1999),

Linda Addison, "A Teacher's Reflection on the Implementation of Journal Writing in Mathematics", Thesis, master of education, the Faculty of Education of the University of Lethbridge, Alberta, 1995.

Linda Gerot and Peter Wignell, Making Sense of Functional Grammar, Sydney: Gred Stabler,

Martha Rapp Ruddell, Teaching Content Reading and Writing, (New Jersey: Willey Jossey-Bass Education, 2005)

Mohammed Farouk Abd El Sami Ali, "Using Journal Writing for Developing EFL Pre-service Teachers' Writing Skills and Teaching Performance", http://www.fayoum.edu.eg/English/Education/CurriculaTeaching/pdf/Journal.pdf, accessed on March 13, 2013.

Mukarto, at al, English on Sky SMP Book 1, (Jakarta: Erlangga, 2004)

Oshima and Ann Hogue, Writing Academic English. (New York: Longman, 1999)

Patricia A Antonacci and Catherine M. O Callaghan, A Handbook for Literacy Instructional \& Assessment Strategies K-8, (Boston: Pearson A \& B, 2006)

Rebecca L. Oxford, Language Learning Strategies: What Every Teacher Should Know, (Boston: Heinle \& Heinle Publisher, 1990)

Rosa M. Manchon, Learning-to-Write and Writing-to-Learn in an Additional Language, (Amsterdam: John Benjamins Publishing Company, 2011)

Suzanne F. Peregoy, and Owen F. Boyle, Reading, Writing, and Learning in ESL: Fifth Edition, (Boston: Pearson Education, 2008)

Ulfah Fitri Ikayati, "Teaching Writing Recount through Daily Activity", Thesis, Faculty of Teaching Learning and Education University of Ibnu Khaldun English Department, Bogor, 2009. 